\title{
Immunohistochemical Localization of Estrogen Receptors in Human Spermatozoa
}

\author{
Pankaj K Sharma $^{1 *}$, Kapil Kumar ${ }^{2}$, S Jayaraman ${ }^{3}$ \\ ${ }^{I}$ National Institute of Biologicals, Noida \\ ${ }^{2}$ Department of Zoology, Meerut College, Meerut \\ ${ }^{3}$ National Institute of Pathology, Indian Council of Medical Research (ICMR), Safdarjung Hospital Campus, \\ New Delhi
}

*Corresponding Author: Pankaj K Sharma, National Institute of Biologicals, Noida

\begin{abstract}
The functional role of Estrogen and Estrogen receptor (ER) in the normal male sperm has not been well understood. An investigation was undertaken to establish the presence of estrogen receptors in human spermatozoa. The immunochemical studies indicated the localization of Estrogen receptor $\alpha$, Estrogen receptor $\beta$, in the ejaculated human spermatozoa of 50 men. The presence of both types of Estrogen receptors re-emphasize the important role of estrogen in male reproduction that may possibly be use for diagnosis and treatment of idiopathic male infertility or may be used for development of new contraceptives in future.
\end{abstract}

Keywords: Avidin Biotin Peroxidase complex Kit (ABC Kit); 3,3' Diaminobenzidin (DAB); Estrogen; Estrogen receptors; Immunohistochemistry; and Human Spermatozoa

\section{INTRODUCTION}

According to World Health Organization (WHO), male factor plays critical role in declining fertility in human [1]. Demonstration of decrease fertility in male mice due to estrogen receptor gene disruption point toward important role in male reproduction [2]. The Estrogen Receptors ( $\alpha$ and $\beta$ ) have been identified in a number of reproductive tissues of the male by immunochemical and molecular biology techniques [3]. Estradiol $17 \beta$ mediates its physiological action by changing the expression profiles of target genes within the responsive tissues [4, 5]. In-vivo mutations in ER $\alpha$ gene have demonstrated the necessity for ER $\alpha$ mediated action in the male fertility [6]. Further estrogen can bind to membrane receptors and trigger rapid changes in the electrolyte transport systems, being referred as 'non-genomic' action of estrogen [7]. Systemic administration of the antiestrogen, Tamoxifen induces reversible sterility in male rats and monkeys $[8,9]$. The objective of this study was to confirm the expression of Estrogen receptor (ER $\alpha$ and ER $\beta$ ) in the spermatozoa of fertile human using immunochemical techniques. It is believed that such a demonstration would further improve the understandings on the role of estrogen in the male fertility.

\section{Materials AND Methods}

\subsection{Chemicals and Reagents}

All the general chemicals and reagents, except where specified otherwise, were procured from Sigma Aldrich (USA). The ER- $\alpha$ antibodies (Clone 1D5) used in the immunochemical studies were procured from Thermo Fisher Scientific (USA), ER- $\beta$ antibodies (B1) from Santa Cruz Biotechnology (USA) and Vectastain Elite ABC Kit (Mouse IgG) from Vector Laboratories (USA).

\subsection{Collection and Analysis of Semen}

Samples were collected in accordance to guidelines issued by Indian Council of Medical Research "ICMR ethical guidelines for biomedical research on human subject". Left over anonymous semen samples were used from individuals who were undergoing semen analysis for couple infertility. and exhibited Normospernia, a sperm count of at least $40 \times 10^{6} / \mathrm{mL}$ spermatozoa and fulfilling the color, volume, spermatozoan morphology, viscosity, motility, vitality and falling in criteria recognized for 
fertile group as per WHO [10] were included for the study. The samples with a linear progressive motility of less than $50 \%$ and with leukocytes and/or immature germ cell concentration greater than $10^{6} / \mathrm{mL}$ were not included in the study Semen samples were collected in pre-sterilized vials as per WHO recommendations and incubated at $37^{\circ} \mathrm{C}$ for 15 minutes. After liquefaction routine semen analyses were performed [10]. Seminal smears were prepared from the semen samples air-dried and fixed for $20 \mathrm{~min}$ in $95 \%$ ethanol and stored till further analysis [10].

\subsection{Immunochemical Study}

Immunohistochemical localization of ER- $\alpha$ [11] and ER- $\beta$, were carried out using specific monoclonal primary antibodies [12]. Endogenous peroxidase activity was quenched using $0.3 \%$ Hydrogen peroxide $\left(\mathrm{H}_{2} \mathrm{O}_{2}\right)$ in methanol. Each batch of the 10 slides was processed for immunochemical studies as per manufacturer's instructions for use. Vactastain Elite ABC-HRP Kit (Peroxidase, Mouse IgG) was used immunohistochemical staining. The staining was carried out along with isotype specific negative and positive control that was Estrogen receptor positive breast Carcinoma (not shown).

Primary antibodies were visualized by using Vactastain Elite ABC Kit and ImmPACT DAB as substrate and counter stained with Haematoxylin [12].

Validity of each run procedure has been confirmed by checking negative and positive control before compelling results.

Nikon upright microscope fitted with digital photography unit were used for capturing microphotographs. (Courtesy: National Institute of Health and Family Welfare, New Delhi).

\section{RESULTS AND DISCUSSION}

Results of only valid run procedure were included in the study. Deposition of brown color DAB clearly indicate the presence of Estrogen Receptor- $\alpha$ (Fig.1) and Estrogen Receptor- $\beta$ (Fig.2) and no brown deposition was observed in isotype specific negative control (Fig.3)

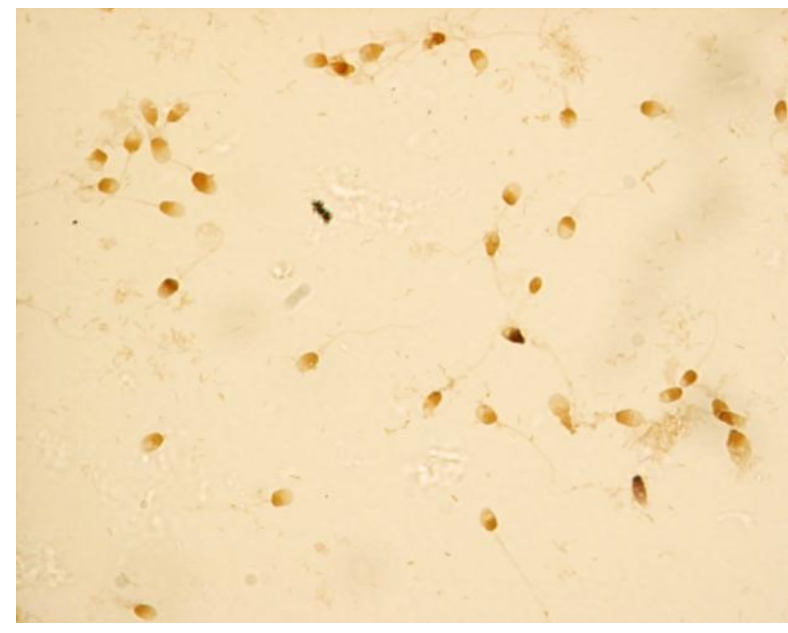

Figure1. Estrogen Receptor- $\alpha, 100 x$

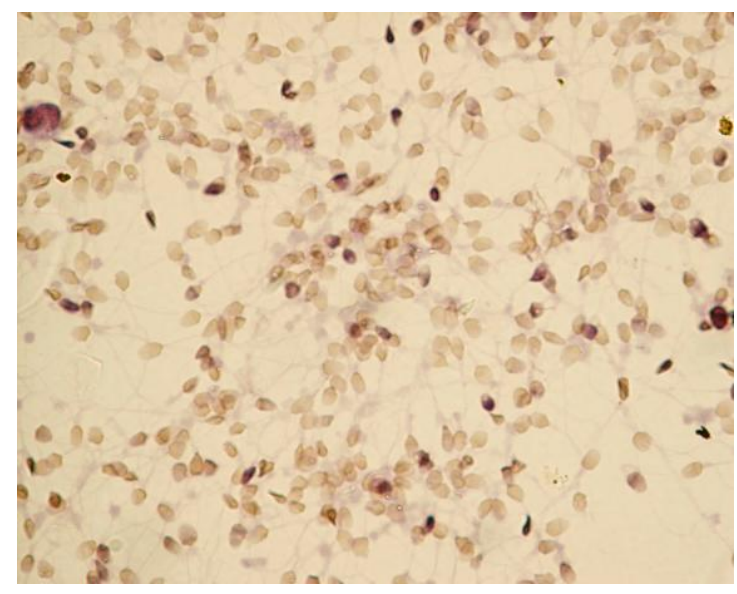

Figure2. Estrogen Receptor- $\beta, 100 x$ 


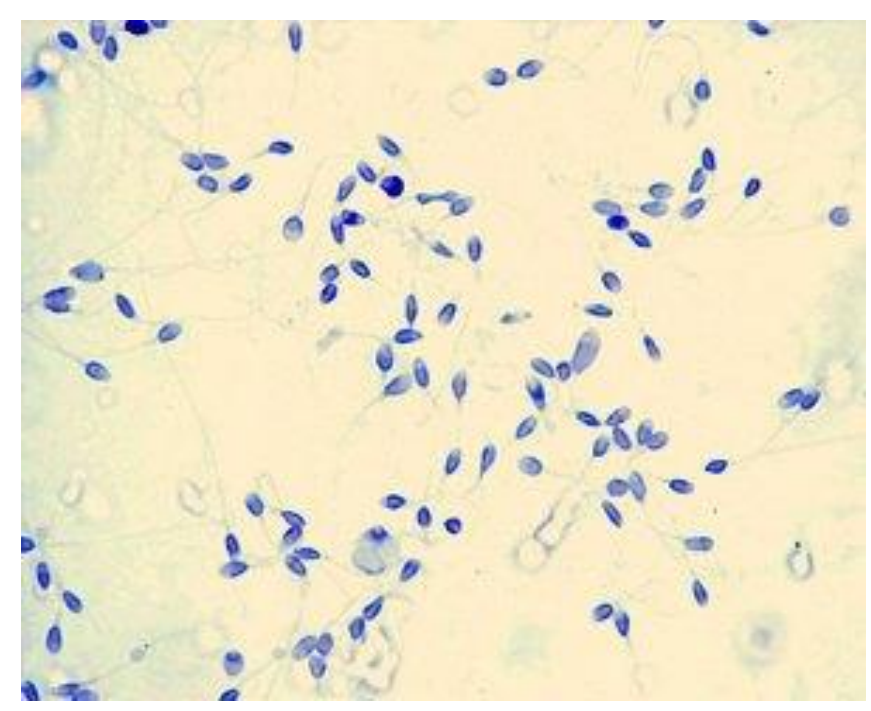

Figure3. Negative Control, 100x

Brown color was mainly observed in post-acrosome (nuclear) region of the head of spermatozoa in all 50 Normospernic subjects, though the mid piece of spermatozoa showed mild localizations. Observation clearly indicate the presence of both ER- $\alpha$ and ER- $\beta$ in the Human spermatozoa

It was observed that ER- $\beta$ localizations are light colored than ER $\alpha$, with similar pattern as was seen in ER $\alpha$. Very mild brown color was observed in mid piece and tail of some of spermatozoa. Some of abnormal spermatozoa showed variable localizations. During the investigations, though postacrosomal region of sperm head showed the presence of ER $\alpha, E R \beta$ in the entire population though the intensity varied but all of them were positive.

Generation of knockout mouse for ER- $\alpha(\mathrm{ER} \alpha \mathrm{KO})$ has indicated the important role of estrogens in the maintenance of spermatogenesis and fertility [13-15]. Though the reports on the presence of ER- $\alpha$ and $\beta$ on spermatozoa are available but specific role of estrogen receptors in the spermatozoa is still is not clear [16-18] and needs further understandings.

Localization of ERs on spermatozoa to clarify role of Estrogen in male reproduction was reported in numerous studies, though the outcomes of the studies are not always in agreement. In the year of 1979 a study was conducted that confirm the binding of hormone to membrane of spermatozoa [19]. Location of binding site were mainly on mid piece fewer on head and neck minimum on tail [20]. The presence of nuclear or cytosolic Estrogen Receptors was excluded in the human spermatozoa [21]. Later immunohistochemical and molecular presence of Estrogen Receptors and its mRNA were also reported in spermatozoa [3, 18]. Difference can be found in localization and molecular weight in different studies varies between species [22]. Interestingly, one study reported Estrogen receptor $\alpha$ truncated variant of $46 \mathrm{kDa}$ were detected in mature human spermatozoa [23]. Molecular weight of full length Estrogen receptor $\alpha$ is $66 \mathrm{kDa}$ and $46 \mathrm{kDa}$ may represent truncated splice variant of Estrogen receptor $\alpha$ [24].

Studies revealed that most of Estrogen receptor $\beta$ knockout (ER $\beta K O)$ male mouse models are fertile $[25,26]$. Some report state that there are several splice variant of Estrogen receptor $\beta$ detected in the ER $\beta K O$ ovaries [26]. These splice variants of Estrogen receptor $\beta$ could be present in testis and may be compensation for lack of complete Estrogen receptor $\beta$ as it is predominant variant of ER in the testis [27]. The generation of new ER $\beta K O$ lacking splice variants as detected in previous models was contradictorily sterile and lack Estrogen receptor $\beta$ in the ovaries and testis [28]. A novel estrogen receptor of smaller size $(29 \mathrm{kDa})$ has been identified on the membrane of human spermatozoa that may mediate consequence on human spermatozoa [29]. No further investigation have been studied this in more detail [22].

During the investigations, though post-acrosomal region of sperm head showed the presence of ER $\alpha$ and ER $\beta$ in the entire population though the intensity varied but all of them were positive. It is also known that ER does not work in isolation and many signaling factors comprise growth factors can influence or be influenced by ER signaling [30-32]. 


\section{CONCLUSION}

The available information can be summarized as

(a) The presence of ER $\beta$ receptor in spermatozoa, perhaps playing an important role in estrogen signaling and modulating the biological activity ER $\alpha$ [30-32]

(b) Reports on the existence of non-genomic pathway for Estrogen (Steroid Hormone) rapid action on spermatozoa.

(c) Progesterone Receptor (PR) expression regulation by ER [29].

(d) Documented in-vitro physiological action of estrogen on spermatozoan function suggesting that estrogen has some important but unrecognized physiological action in spermatozoa function.

The possibility of the above is also supported by our earlier observations in some that some infertile subjects spermatozoa were deficient in estrogen receptor $\alpha$ when evaluated immunochemically with ER monoclonal antibody. All the above information strongly suggests that these ERs either alone or in combination plays crucial role in male reproduction. Further studies are now required to elucidate the mechanism of action of estrogens on human male reproduction in terms of both genomic and 'nongenomic' pathways.

\section{REFERENCES}

[1] Cooper, T.G., et al., World Health Organization reference values for human semen characteristics. Hum Reprod Update, 2010. 16(3): p. 231-45.

[2] Lubahn, D.B., et al., Alteration of reproductive function but not prenatal sexual development after insertional disruption of the mouse estrogen receptor gene. Proc Natl Acad Sci U S A, 1993. 90(23): p. 11162-6.

[3] Durkee, T.J., M. Mueller, and M. Zinaman, Identification of estrogen receptor protein and messenger ribonucleic acid in human spermatozoa. Am J Obstet Gynecol, 1998. 178(6): p. 1288-97.

[4] Josephy, P.D., Re:Feigelson, H.S. and Henderson,B.E.(1996) Estrogens and breast cancer. Carcinogenesis, 17, 2279-2284. Carcinogenesis, 1997. 18(9): p. 1859-60.

[5] Nilsson, S., et al., Mechanisms of estrogen action. Physiol Rev, 2001. 81(4): p. 1535-65.

[6] Hess, R.A., Estrogen in the adult male reproductive tract: a review. Reprod Biol Endocrinol, 2003. 1: p. 52.

[7] Morley, P., et al., A new, nongenomic estrogen action: the rapid release of intracellular calcium. Endocrinology, 1992. 131(3): p. 1305-12.

[8] Gill-Sharma, M.K., et al., Effects of tamoxifen on the fertility of male rats. J Reprod Fertil, 1993. 99(2): p. 395-402.

[9] Rao, A.J., et al., Effect of chronic administration of Tamoxifen on fertility in male bonnet monkeys (Macaca radiata). Andrologia, 1998. 30(3): p. 129-32.

[10] WHO, WHO laboratory manual for the Examination and processing of human semen, ed. W.H. Organization. 2010, Switzerland: WHO Press, World Health Organization, Switzerland. 1-271.

[11] Bukovsky, A., et al., Expression and localization of estrogen receptor-alpha protein in normal and abnormal term placentae and stimulation of trophoblast differentiation by estradiol. Reproductive Biology and Endocrinology, 2003. 1(1): p. 13.

[12] Hsu, S.M., L. Raine, and H. Fanger, Use of avidin-biotin-peroxidase complex (ABC) in immunoperoxidase techniques: a comparison between $\mathrm{ABC}$ and unlabeled antibody (PAP) procedures. $\mathrm{J}$ Histochem Cytochem, 1981. 29(4): p. 577-80.

[13] Eddy, E.M., et al., Targeted disruption of the estrogen receptor gene in male mice causes alteration of spermatogenesis and infertility. Endocrinology, 1996. 137(11): p. 4796-805.

[14] Fisher, C.R., et al., Characterization of mice deficient in aromatase (ArKO) because of targeted disruption of the cyp19 gene. Proc Natl Acad Sci U S A, 1998. 95(12): p. 6965-70.

[15] Lee, K.H., et al., Estrogen receptor alpha has a functional role in the mouse rete testis and efferent ductules. Biol Reprod, 2000. 63(6): p. 1873-80.

[16] Kuiper, G.G., et al., Cloning of a novel receptor expressed in rat prostate and ovary. Proc Natl Acad Sci U S A, 1996. 93(12): p. 5925-30.

[17] Couse, J.F. and K.S. Korach, Estrogen receptor null mice: what have we learned and where will they lead us? Endocr Rev, 1999. 20(3): p. 358-417. 
[18] Misao, R., et al., Immunohistochemical detection of estrogen and progesterone receptors in spermatozoa of infertile men. Int J Fertil Womens Med, 1997. 42(6): p. 421-5.

[19] Hernandez-Perez, O., L.M. Ballesteros, and A. Rosado, Binding of 17-beta-estradiol to the outer surface and nucleus of human spermatozoa. Arch Androl, 1979. 3(1): p. 23-9.

[20] Cheng, C.Y., et al., The binding of sex steroids to human spermatozoa. An autoradiographic study. Int J Androl, 1981. 4(1): p. 1-17.

[21] Cheng, C.Y., B. Boettcher, and R.J. Rose, Lack of cytosol and nuclear estrogen receptors in human spermatozoa. Biochem Biophys Res Commun, 1981. 100(2): p. 840-6.

[22] Dostalova, P., E. Zatecka, and K. Dvorakova-Hortova, Of Oestrogens and Sperm: A Review of the Roles of Oestrogens and Oestrogen Receptors in Male Reproduction. Int J Mol Sci, 2017. 18(5).

[23] Lambard, S., et al., Human immature germ cells and ejaculated spermatozoa contain aromatase and oestrogen receptors. J Mol Endocrinol, 2004. 32(1): p. 279-89.

[24] Solakidi, S., et al., Estrogen receptors alpha and beta (ERalpha and ERbeta) and androgen receptor (AR) in human sperm: localization of ERbeta and AR in mitochondria of the midpiece. Hum Reprod, 2005. 20(12): p. 3481-7.

[25] Dupont, S., et al., Effect of single and compound knockouts of estrogen receptors alpha (ERalpha) and beta (ERbeta) on mouse reproductive phenotypes. Development, 2000. 127(19): p. 4277-91.

[26] Krege, J.H., et al., Generation and reproductive phenotypes of mice lacking estrogen receptor beta. Proc Natl Acad Sci U S A, 1998. 95(26): p. 15677-82.

[27] Shaha, C., Estrogens and spermatogenesis. Adv Exp Med Biol, 2008. 636: p. 42-64.

[28] Antal, M.C., et al., Sterility and absence of histopathological defects in nonreproductive organs of a mouse ERbeta-null mutant. Proc Natl Acad Sci U S A, 2008. 105(7): p. 2433-8.

[29] Luconi, M., et al., Identification and characterization of a novel functional estrogen receptor on human sperm membrane that interferes with progesterone effects. J Clin Endocrinol Metab, 1999. 84(5): p. 16708.

[30] Nicholson, R.I. and J.M. Gee, Oestrogen and growth factor cross-talk and endocrine insensitivity and acquired resistance in breast cancer. Br J Cancer, 2000. 82(3): p. 501-13.

[31] Nicholson, R.I., et al., Modulation of epidermal growth factor receptor in endocrine-resistant, oestrogen receptor-positive breast cancer. Endocr Relat Cancer, 2001. 8(3): p. 175-82.

[32] Nicholson, R.I., et al., Nonendocrine pathways and endocrine resistance: observations with antiestrogens and signal transduction inhibitors in combination. Clin Cancer Res, 2004. 10(1 Pt 2): p. 346S-54S.

Citation: P. Sharma, "Immunohistochemical Localization of Estrogen Receptors in Human Spermatozoa", International Journal of Research Studies in Biosciences (IJRSB), vol. 5, no. 11, pp. 14-18, 2017. http://dx.doi. org/10.20431/2349-0365.0511003

Copyright: (c) 2017 Authors. This is an open-access article distributed under the terms of the Creative Commons Attribution License, which permits unrestricted use, distribution, and reproduction in any medium, provided the original author and source are credited. 